\title{
Influence of Temperature Variation on Emamectin Benzoate Toxicity in Different Leucinodes orbonalis Guenee Populations of Punjab
}

\author{
A.K. Chandi, A. Kaur and R.S. Chandi \\ Department of Entomology, Punjab Agricultural University, Ludhiana-141 004, India \\ E-mail: anureetchandi@pau.edu
}

\begin{abstract}
In present study, larval populations of $L$. orbonalis, collected from different regions of Punjab i.e. Amritsar, Kapurthala, Malerkotla,

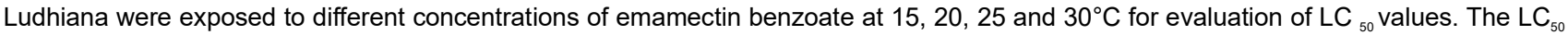
decreased from lower $\left(15^{\circ} \mathrm{C}\right)$ to higher $\left(30^{\circ} \mathrm{C}\right)$ temperature for all populations of $L$. orbonalis. The positive correlation was observed between the temperature coefficient and emamectin benzoate toxicity towards population of $L$. orbonalis, which increased with increase in temperature. The $\mathrm{LC}_{50}$ values varied among different populations of $L$. orbonalis i.e. Amritsar populations with higher $\mathrm{LC}_{50}$ followed by Kapurthala, Malerkotla and Ludhiana populations. The temperature and insecticide exposure history affected the toxicity of emamectin benzoate toxicity for $L$. orbonalis. The information would be helpful in developing management strategies for $L$. orbonalis according to prevailing environment conditions.
\end{abstract}

Keywords: Leucinodes orbonalis, Emamectin benzoate, Temperature coefficient, Punjab

Brinjal shoot and fruit borer, Leucinodes orbonalis Guenee is the obnoxious and destructive pest which is widely distributed throughout world which includes India, East Africa, USA, Germany, Pakistan and Sri Lanka (Rashid et al 2008, Onekutu et al 2013, Chandi and Kaur 2021). In India, this pest is considered as primary and severe pest of brinjal which can cause considerable damage and losses to brinjal crop from 70 to 92 percent (Chakraborti and Sarkar 2011, Onekutu et al 2013).This pest poses serious damage to brinjal crop from the nursery stage till the harvesting The larvae of $L$. orbonalis bore into tender shoots of young plants, causing drooping and withering of growing tips. In the later stage flower buds and fruits are also infested. The high temperature and relative humidity are major factors contributing to major yield losses due to $L$. orbonalis. (Jhala et al 2007, Kaur et al 2014, Singla 2014). Insecticidal control is most preferred control strategy for management of this pest (Chandi and Kaur 2021). The excessive use of insecticides for control of this insect-pest has led to problems such as insecticide residues in fruits and development of resistance (Onekutu et al 2013, Kaur et al 2014, Chandi and Kaur 2021).

Emamectin benzoate, a semisynthetic derivative of abamectin and is effective insecticide against $L$. orbonalis (Anil and Sharma 2011, Chandi and Kaur 2021). The neurotransmitter, $Y$-aminobutyric acid (GABA) release activating chloride channels are main site of action for this insecticide affecting functioning of nerve impulses in insect pest (Tong et al 2013, Bengochea et al 2014). This compound also exhibits translaminar activity and longer long-term residual pest control by maintenance of active substance in treated leaves for longer through larval feeding (López et al 2011, Bengochea et al 2014). Efficacy of any insecticide towards any insect pest is influenced by temperature variations due to high dependence of insecticide degradation metabolic activities in insects on temperature (Khan and Akram 2014, Glunt et al 2018, Jaleel et al 2019). The present study was conducted to investigate the toxicity of emamectin benzoate towards different populations of $L$. orbonalis collected from different regions of Punjab with respect to variations in temperature.

\section{MATERIAL AND METHODS}

Culture of $L$. orbonalis:: The infested shoots and fruits of brinjal were collected from vegetable fields of Amritsar ( $31^{\circ}$ $37^{\prime} 20.42^{\prime \prime} \mathrm{N}$ and $74^{\circ} 52^{\prime} 31.22^{\prime \prime} \mathrm{E}$ ), Kapurthala ( $31^{\circ} 22^{\prime} 47.99^{\prime \prime}$ $\mathrm{N}$ and $\left.75^{\circ} 22^{\prime} 47.98^{\prime \prime} \mathrm{E}\right)$, Malerkotla $\left(30^{\circ} 31^{\prime} 23.54^{\prime \prime} \mathrm{N}\right.$ and $75^{\circ}$ $53^{\prime} 17.70^{\prime \prime} \mathrm{E}$ ) and Ludhiana ( $30^{\circ} 53^{\prime} 60.00^{\prime \prime} \mathrm{N}$ and $75^{\circ} 50^{\prime} 60.00$ $E)$ regions. The larvae of $L$. orbonalis were extracted from fruits and shoots of brinjal and reared in the Insect Physiology laboratory. Larvae of $L$. orbonalis collected from brinjal fruits were transferred to the glass jar $(10 \times 15 \mathrm{~cm})$ containing fresh pieces of brinjal fruit and placed in an incubator at $27^{\circ} \mathrm{C}$ and 70 per cent relative humidity $(\mathrm{RH}$, and the food was changed daily in the morning hours to prevent fungal contamination till the fifth instar larvae got ready for pupation. The pupae were shifted to second set of glass jars, containing moist sponge at base and covered with muslin cloth for pupation. The 
emerging adults were sexed and transferred into new jars for mating and oviposition on the same day. A cotton swab dipped in 10 per cent honey solution as a food source to adults. The leaf with eggs laid upon was removed daily and replaced with a new one to facilitate further oviposition.

Rearing of susceptible population of $L$. orbonalis: $L$. orbonalis population collected from infested fruits of brinjal fields of Punjab Agricultural University, Ludhiana was reared for twenty generations to develop susceptible population.

Toxicity bioassay: Populations of $L$. orbonalis collected from different regions of Punjab i.e. Amritsar, Kapurthala, Malerkotla and Ludhiana were reared up to $F_{1}$ generation. For conducting toxicity bioassay, six different concentrations of test insecticide i.e. emamectin benzoate were prepared by serial dilutions. The 'fruit dip' bioassay method (Kodandaram et al 2017) was implied to determine LC $_{50}$ values of test insecticide against third instar larvae of all the selected populations. The small slices of brinjal fruits were dipped in different concentrations of insecticide for 30 seconds, air dried and placed in glass jars. The ten $3^{\text {rd }}$ instar larvae of $L$. orbonalis were allowed to feed on treated fruit-discs kept at different temperatures i.e. 15, 20, 25 and $30^{\circ} \mathrm{C}$ for 48 hours. Experiment was conducted with three replications and ten larvae per replication. The mortality was recorded 48 hours respectively. Mortality in all the treatments was corrected by Abbott's formula (Abott 1925).

Data analysis: The log concentration-mortality regression was worked out by the computer programme POLO (Robertson et al 1980). Temperature coefficients of insecticide (emamectin benzoate) were also calculated (Musser and Shelton 2005).

\section{RESULTS AND DISCUSSION}

There was positive influence of temperature variation on toxicity levels of emamectin benzoate in different populations of $L$. orbonalis collected from different regions of Punjab. The positive correlation was observed between tested temperature range and toxicity of emamectin benzoate in both year i.e. 2019 and 2020 (Table 1). In year 2019 the decrease in $\mathrm{LC}_{50}$ values was observed from $15^{\circ} \mathrm{C}$ to $30^{\circ} \mathrm{C}$ for all populations of $L$. orbonalis. In terms of $L C_{50}$ values, the toxicity of emamectin benzoate was 1.11 and 1.36 times higher at $20^{\circ} \mathrm{C}$ and $30^{\circ} \mathrm{C}$ as compared to $15^{\circ} \mathrm{C}$ for populations of Amritsar region. Similarly for Kapurthala population at $20^{\circ} \mathrm{C}$ and $30^{\circ} \mathrm{C}$ was. 1.17 to 1.52 folds respectively. The Malerkotla population showed 1.68 times

Table 1. Temperature variation influence on toxicity of emamectin benzoate in L. orbonalis in year 2019

\begin{tabular}{|c|c|c|c|c|c|c|c|c|}
\hline \multirow[t]{2}{*}{ Region } & \multirow{2}{*}{$\begin{array}{c}\text { Temperature } \\
\left({ }^{\circ} \mathrm{C}\right)\end{array}$} & \multirow[t]{2}{*}{$\mathrm{LC}_{50}(\%)$} & \multicolumn{2}{|c|}{ Fiducial limits } & \multirow[t]{2}{*}{ Slope \pm S.E } & \multicolumn{3}{|c|}{ Temperature coefficient } \\
\hline & & & Lower limit & Upper limit & & $5^{\circ} \mathrm{C}$ & $10^{\circ} \mathrm{C}$ & $15^{\circ} \mathrm{C}$ \\
\hline \multirow[t]{4}{*}{ Amritsar } & 15 & 0.000060 & 0.000044 & 0.000061 & $1.34 \pm 0.97$ & - & - & - \\
\hline & 20 & 0.000054 & 0.000042 & 0.000056 & $1.08 \pm 0.60$ & 1.11 & - & - \\
\hline & 25 & 0.000048 & 0.000039 & 0.000053 & $2.62 \pm 1.33$ & 1.12 & 1.25 & - \\
\hline & 30 & 0.000044 & 0.000026 & 0.000052 & $2.14 \pm 1.24$ & 1.09 & 1.22 & 1.36 \\
\hline \multirow[t]{4}{*}{ Kapurthala } & 15 & 0.000055 & 0.000039 & 0.000060 & $2.08 \pm 0.62$ & - & - & - \\
\hline & 20 & 0.000047 & 0.000025 & 0.000058 & $2.18 \pm 1.40$ & 1.17 & - & - \\
\hline & 25 & 0.000041 & 0.000032 & 0.000055 & $1.52 \pm 0.92$ & 1.14 & 1.34 & - \\
\hline & 30 & 0.000036 & 0.000028 & 0.000047 & $2.17 \pm 1.43$ & 1.13 & 1.30 & 1.52 \\
\hline \multirow[t]{4}{*}{ Malerkotla } & 15 & 0.000042 & 0.000033 & 0.000060 & $1.70 \pm 0.56$ & - & - & - \\
\hline & 20 & 0.000034 & 0.000020 & 0.000041 & $2.48 \pm 1.22$ & 1.23 & - & - \\
\hline & 25 & 0.000030 & 0.000022 & 0.000038 & $1.71 \pm 1.90$ & 1.13 & 1.40 & - \\
\hline & 30 & 0.000025 & 0.000018 & 0.000030 & $2.32 \pm 1.52$ & 1.20 & 1.36 & 1.68 \\
\hline \multirow[t]{4}{*}{ Ludhiana } & 15 & 0.000037 & 0.000031 & 0.000062 & $1.62 \pm 0.88$ & - & - & - \\
\hline & 20 & 0.000030 & 0.000015 & 0.000035 & $1.65 \pm 1.20$ & 1.23 & - & - \\
\hline & 25 & 0.000025 & 0.000011 & 0.000038 & $2.77 \pm 1.35$ & 1.20 & 1.48 & - \\
\hline & 30 & 0.000021 & 0.000010 & 0.000040 & $2.50 \pm 0.75$ & 1.19 & 1.42 & 1.76 \\
\hline \multirow[t]{4}{*}{ Susceptible } & 15 & 0.000030 & 0.000028 & 0.000042 & $1.66 \pm 1.05$ & - & - & - \\
\hline & 20 & 0.000022 & 0.000016 & 0.000035 & $1.18 \pm 0.73$ & 1.36 & - & - \\
\hline & 25 & 0.000016 & 0.000008 & 0.000025 & $2.05 \pm 1.11$ & 1.37 & 1.87 & - \\
\hline & 30 & 0.000012 & 0.000010 & 0.000028 & $2.20 \pm 1.03$ & 1.33 & 1.83 & 2.50 \\
\hline
\end{tabular}


Table 2. Temperature variation influence on toxicity of emamectin benzoate in L. orbonalis in year 2020

\begin{tabular}{|c|c|c|c|c|c|c|c|c|}
\hline \multirow[t]{2}{*}{ Region } & \multirow{2}{*}{$\begin{array}{c}\text { Temperature } \\
\left({ }^{\circ} \mathrm{C}\right)\end{array}$} & \multirow[t]{2}{*}{$\mathrm{LC}_{50}(\%)$} & \multicolumn{2}{|c|}{ Fiducial limits } & \multirow[t]{2}{*}{ Slope \pm S.E } & \multicolumn{3}{|c|}{ Temperature coefficient } \\
\hline & & & Lower limit & Upper limit & & $5^{\circ} \mathrm{C}$ & $10^{\circ} \mathrm{C}$ & $15^{\circ} \mathrm{C}$ \\
\hline \multirow[t]{4}{*}{ Amritsar } & 15 & 0.000064 & 0.000053 & 0.000068 & $1.16 \pm 1.12$ & - & - & - \\
\hline & 20 & 0.000058 & 0.000048 & 0.000065 & $2.32 \pm 1.98$ & 1.10 & - & - \\
\hline & 25 & 0.000053 & 0.000050 & 0.000058 & $2.61 \pm 1.03$ & 1.09 & 1.20 & - \\
\hline & 30 & 0.000048 & 0.000047 & 0.000056 & $2.18 \pm 1.06$ & 1.10 & 1.20 & 1.33 \\
\hline \multirow[t]{4}{*}{ Kapurthala } & 15 & 0.000061 & 0.000044 & 0.000065 & $1.55 \pm 0.95$ & - & - & - \\
\hline & 20 & 0.000050 & 0.000039 & 0.000053 & $2.22 \pm 1.55$ & 1.22 & - & - \\
\hline & 25 & 0.000047 & 0.000036 & 0.000051 & $1.88 \pm 0.52$ & 1.06 & 1.29 & - \\
\hline & 30 & 0.000040 & 0.000032 & 0.000050 & $2.14 \pm 1.35$ & 1.17 & 1.25 & 1.52 \\
\hline \multirow[t]{4}{*}{ Malerkotla } & 15 & 0.000048 & 0.000028 & 0.000034 & $2.05 \pm 1.23$ & - & - & - \\
\hline & 20 & 0.000038 & 0.000023 & 0.000043 & $1.15 \pm 0.70$ & 1.26 & - & - \\
\hline & 25 & 0.000035 & 0.000026 & 0.000056 & $2.28 \pm 1.72$ & 1.08 & 1.37 & - \\
\hline & 30 & 0.000031 & 0.000029 & 0.000047 & $1.45 \pm 1.32$ & 1.12 & 1.22 & 1.54 \\
\hline \multirow[t]{4}{*}{ Ludhiana } & 15 & 0.000042 & 0.000026 & 0.000053 & $2.66 \pm 1.04$ & - & - & - \\
\hline & 20 & 0.000034 & 0.000018 & 0.000038 & $2.06 \pm 0.80$ & 1.23 & - & - \\
\hline & 25 & 0.000030 & 0.000022 & 0.000032 & $2.83 \pm 1.91$ & 1.13 & 1.40 & - \\
\hline & 30 & 0.000026 & 0.000020 & 0.000031 & $2.28 \pm 0.93$ & 1.15 & 1.30 & 1.61 \\
\hline \multirow[t]{4}{*}{ Susceptible } & 15 & 0.000033 & 0.000043 & 0.000054 & $1.95 \pm 1.16$ & - & - & - \\
\hline & 20 & 0.000027 & 0.000036 & 0.000050 & $2.71 \pm 0.64$ & 1.22 & - & - \\
\hline & 25 & 0.000020 & 0.000018 & 0.000042 & $1.54 \pm 0.87$ & 1.35 & 1.65 & - \\
\hline & 30 & 0.000017 & 0.000010 & 0.000038 & $1.30 \pm 1.61$ & 1.17 & 1.58 & 1.94 \\
\hline
\end{tabular}

higher emamectin benzoate toxicity at $30^{\circ} \mathrm{C}$ as compared to 1.23 folds at $20^{\circ} \mathrm{C}$. The increase in emamectin bezoate toxicity was observed at $30^{\circ} \mathrm{C}$ i.e. 1.76 times as compared to 1.23 times at $20^{\circ} \mathrm{C}$ for Ludhiana population of $L$. orbonalis. The emamectin benzoate toxicity for susceptible population was 2.50 times higher at $30^{\circ} \mathrm{C}$ as compared to 1.36 at $20^{\circ} \mathrm{C}$. The emamectin benzoate toxicity was low for Amritsar population followed by Malerkotla, Kapurthala and Ludhiana populations. During 2020 (Table 2) the increase in LC $_{50}$ values were recorded as compared to 2019 for all populations of $L$. orbonalis. The trend of toxicity with respective to different temperatures was similar as of 2019 i.e. higher toxicity of emamectin benzoate at $30^{\circ} \mathrm{C}$. Khan and Akram (2014) reported positive correlation between the temperature and toxicity of emamectin benzoate in-house fly, Musca domestica (Linnaeus). Similarly Teja et al (2018) also observed increase in emamectin benzoate toxicity towards Plutella xylostella (Linnaeus) at higher temperature. Li et al (2004) observed that enhancement in toxicity emamectin benzoate of towards $P$. xylostella with increase in temperature. Toxicity of insecticides with a positive temperature coefficient tends to increase at higher temperatures ranges (Glunt et al 2013). The change in toxicity levels of emamectin benzoate could be due to variation in biotransformation process, i.e. at lower temperature the biotransformation might decrease leading to elevated level of the original compounds which possess low toxicity than other secondary compounds formed through biotransformation (Harwood et al 2009, Khan and Akram 2014).

The variation in the $\mathrm{LC}_{50}$ values and toxicity between various populations of $L$. orbonalis (Amritsar, Kapurthala, Malerkotla, and Ludhiana) could be due to difference in insecticide exposure history of all populations of $L$. orbonalis. Earlier studies by Chandi and Kaur (2021) also revealed that $\mathrm{LC}_{50}$ values of Amritsar population were higher as compared to Kapurthala and Ludhiana for emamectin benzoate. The amount and of insecticide applied for control of any pest in any particular area plays an important role in development of pest resistance along with other physical and biological factors (Helps and Van den Bosch 2017).

\section{CONCLUSION}

In present investigation both temperature and insecticide exposure background of $L$. orbonalis acted as vital factors for toxicity of emamectin benzoate, but there is 
need of detailed study about the mechanism that have led to variation in emamectin benzoate toxicity. The present study would be helpful in developing management strategies for efficient control of $L$. orbonalis by emamectin benzoate in changing scenario of climate change.

\section{REFERENCES}

Abbott WS 1925. A method of computing the effectiveness of an insecticide. Journal of Economic Entomology 18: 265-267.

Amarasekare KG and Edelson JV 2004. Effect of temperature on efficacy of insecticides to differential grasshopper (Orthoptera: Acrididae). Journal of Economic Entomology 97(5): 15951602.

Anil and Sharma PC 2011. Evaluation of insecticides against brinjal shoot and fruit borer Leucinodes orbonalis Guen. Indian Journal of Entomology 73: 325-330.

Bengochea P, Sánchez-Ramos I, Saelices R, Amor F, Del- Estal P, Viñuela E, Adán A, López A, Budia F and Medina P 2014. Is emamectin benzoate effective against the different stages of Spodoptera exigua (Hübner)(Lepidoptera, Noctuidae)? Irish Journal of Agricultural and Food Research 53: 37-49.

Boina DR, Onagbola EO, Salyani M, Stelinski LL 2009. Influence of post treatment temperature on the toxicity of insecticides against Diaphorina citri (Hemiptera: Psyllidae). Journal of Economic Entomology 102: 685-691.

Botre BS, Salunke PB, Munje SS and Barkhade UP 2014. Monitoring insecticide resistance in Leucinodes orbonalis (Guen). Bioinfolet 11(2B): 521-523.

Chakraborti S and Sarkar PK 2011. Management of L. orbonalis Guenee on eggplants during the rainy season in India. Journal of Plant Protection Research 51: 325-328.

Chandi AK and Kaur A 2021. Evaluation of insecticidal toxicity against Leucinodes orbonalis Guenee populations from Punjab. Agricultural Research Journal 58(2): 344-347.

Finney DJ 1971. Probit Analysis, third ed. Cambridge Press, New York.

Glunt KD, Shüné V, Oliver SV, Hunt RH and Paaijmans KP 2018. The impact of temperature on insecticide toxicity against the malaria vectors Anopheles arabiensis and Anopheles funestus. Malaria Journal 17: 131 https://doi.org/10.1186/s12936-018-2250-4.

Glunt KD, Blanford JI and Paaijmans KP 2013. Chemicals, climate, and control: increasing the effectiveness of malaria vector control tools by considering relevant temperatures. PLOS Pathog. 9 (10),e1003602.

Harwood AD, You J and Lydy MJ 2009. Temperature as a toxicity identification evaluation tool for pyrethroid insecticides: Toxicokinetic confirmation. Environmental Toxicology and Chemistry 28: 1051-1058.

Helps JC and Van den Bosch 2017. Identifying circumstances under which high insecticide dose increases or decreases resistance selection. Journal of Theoretical Biology 428: 153-167.

Ishaaya I, Barazani A. and Horowith AR 2002. Emamectin, a novel insecticide for controlling field crop pests. Pest Management Science 58: 1091-1095.

Jaleel W, Saeed S, Naqqash MN, Sial MU, Ali M, Zaka SM, Sarwar ZM, Ishtiaq M, Qayyum MA, Aine QU, Anwar A, Sarmad M, Azad R, Latif M, Ahmed F, Islam W, Khan KA and Ghramh HA 2019. Effects of temperature on baseline susceptibility and stability of insecticide resistance against Plutella xylostella (Lepidoptera: Plutellidae) in the absence of selection pressure. Saudi Journal of Biological Sciences https://doi.org/10.1016/ j.sjbs.2019.03.004.

Jhala RC, Patel MG, Chavda AJ and Patel YC (ed) 2007. Testing IPM strategy for management of Leucinodes orbonalis in farmer's field. In: Proc Nat Sym Frontier Areas of Entomol, pp 256.

Kalawate A and Dethe MD 2012. Bio efficacy study of Biorational insecticides on brinjal. Journal of Biopesticide 5: 75-80.

Kaur J, Kang BK and Singh B 2014. Base line data for insecticide resistance monitoring in brinjal shoot and fruit borer, Leucinodes orbonalis Guenee. The Bioscan 9: 1395-1398.

Khan HAA and Akram W2014. The effect of temperature on the toxicity of insecticides against Musca domestica L.: Implications for the effective management of diarrhea. PLOS ONE 9(4): e95636.

Kodandaram H, Rai AB, Sharma SK and Singh B 2017. Shift in the level of susceptibility and relative resistance of brinjal shoot and fruit borer Leucinodes orbonalis (Guen) to diamide insecticides. Phytoparasitica 45: 151-154.

$\mathrm{Li} \mathrm{H}$, Zheng F and Luo W 2004. Toxicity of emamectin to the diamondback moth, Plutella xylostella and the effects on survivors of parent generation treated with sublethal dosage. Acta Ecologica Sinica 47: 193-197.

López JA, Amor F, Bengochea P, Medina P, Budia F and Viñuela E 2011. Toxicity of emamectin benzoate to adults of Nesidiocoris tenuis Reuter (Heteroptera: Miridae), Macrolophus pygmaeus (Rambur) (Heteroptera: Miridae) and Diglyphus isaea Walker (Hymenoptera: Eulophidae) on tomato plants. Semi-field studies. Spanish Journal of Agricultural Research 9: 617-622.

Musser FR and Shelton AM 2005. The influence of post-exposure temperature on the toxicity of insecticides to Ostrinia nubilalis (Lepidoptera: Crambidae). Pest Management Science 61: 508510.

Onekutu A, Omoloye AA and Odebiyi JA2013. Biology of eggfruit and shoot borer Leucinodes orbonalis Guenee (Crambidae) on the garden egg Solanum gilo Raddi. Journal of Entomology 10(3): 156-162.

Rashid MH, Mohiuddin M and Mannan MA 2008. Survey and identification of major pest and pest management practices of brinjal during winter at Chittagong district. International Journal of Sustainable Crop Production 3: 27-32.

Robertson JL, Russel RM and Savin NE 1980. POLO: A User's Guide to Probit or Logit Analysis. Pacific South-West fore stand range experiment station, Berkeley, U.S.A.

Sharma A and Sharma PC 2010. Bioefficacy of insecticides against Leucinodes orbonalis on brinjal. Journal of Environmental Biology 31: 399-402.

Singla P 2014. Biology and seasonal incidence of brinjal shoot and fruit borer, Leucinodes orbonalis Guenee. M.Sc. Thesis Punjab Agricultural University, Ludhiana.

Teja N, Sunitha V, Ramesh Babu V and Satyanarayana J 2018. Effect of variable temperature on the toxicity of novel insecticides against diamondback moth, Plutella xylostella (Linn.). Journal of Entomological and Zoological Studies 6(5): 409-412.

Tong H, Su Q, Zhou X and Bai L 2013. Field resistance of Spodoptera litura (Lepidoptera: Noctuidae) to organophosphates, pyrethroids, carbamates and four newer chemistry insecticides in Hunan, China. Journal of Pesticide Science 86: 599-609. 